\title{
RANCANG BANGUN SISTEM PRESENSI MENGGUNAKAN SIDIK JARI (STUDI KASUS PADA LEMBAGA PEMASYARAKATAN KLAS IIA PALU)
}

\section{Designing a Presence System Using Fingerprint (A Case Study In Palu Class II-A Correctional Institution)}

\author{
Amriana $^{1}$, Andi Hendra ${ }^{2}$, Arfiah Bakhtiar ${ }^{3}$ \\ 1,2,3 Jurusan Teknologi Informasi, Fakultas Teknik Universitas Tadulako; \\ e-mail: $\underline{1 \text { ayazih08@yahoo.com, }{ }^{2} \text { a for andie@icloud.com, }{ }^{3} \text { arfiah.bakhtiar@gmail.com }}$
}

\begin{abstract}
Dermatoglyphic has been widely applied to recognize a person's identity, because people basically have something unique or characteristic possessed only by themselves. This raises the idea of making it a unique identity. This is useful for employees presence applications, especially at Lembaga Pemasyarakatan Klas IIA Palu which is still doing manual presence. This system provides the division of labor time and wereable to detect the fingerprints of employees using a fingerprint scanner. The system was made in several stages of the input fingerprint image, binarization fingerprint image, fingerprint image quality improvement, and matching fingerprint image. Improvements to the quality of the fingerprint image consists of the surgical process of mathematical morphology opening and erosion. The detection process of the fingerprint image used euclidean distance measurement points minutiae. The test results indicate that the presence system accuracy using euclidean distance measurement could detect the fingerprint image by $89 \%$ from 20 fingerprint data with 5 times testing for each data.
\end{abstract}

Keywords - fingerprint, presence, mathematical morphology, euclidean distance, minutiae

\section{Pendahuluan}

Ilmu tentang sidik jari (Dermatoglyphic) telah banyak diterapkan untuk mengenali identitas seseorang, karena manusia pada dasarnya memiliki sesuatu yang unik atau khas yang hanya dimiliki oleh dirinya sendiri. Hal ini menimbulkan gagasan untuk menjadikan keunikan tersebut sebagai identitas diri. Hal ini berguna untuk aplikasi presensi pegawai khususnya di Lembaga Pemasyarakatan Klas IIA Palu. Lembaga Pemasyarakatan (Lapas) Klas IIA Palu adalah bagian dari Unit Pelaksanaan Teknis Kementerian Hukum dan HAM di Indonesia khususnya di wilayah Sulawesi Tengah. Kegiatan sehari-hari yang dilakukan oleh para pegawai Lembaga Pemasyarakatan Klas IIA Palu salah satunya adalah melakukan presensi sebelum melanjutkan kegiatan guna mengetahui kehadiran dan kedisiplinan para pegawai. Namun proses presensi pegawai saat ini masih dilakukan secara manual karena adanya masalah dengan aplikasi presensi yang ada sebelumnya sehingga tidak lagi dapat digunakan dan aplikasi tersebut tidak menyediakan jadwal pembagian waktu kerja seperti masuk pagi masuk siang dan masuk malam sehingga tidak sesuai dengan kebutuhan presensi pegawai di Lembaga Pemasyarakatan Klas IIA Palu.

\subsection{Pengenalan Pola}

Pengenalan pola bertujuan menentukan kelompok atau kategori pola berdasarkan ciri-ciri yang 
dimiliki oleh pola tersebut. Pengenalan Pola (Pattern Recognition) adalah suatu ilmu untuk mengklasifikasikan atau menggambarkan sesuatu berdasarkan pengukuran kuantitatif (ciri) atau sifat utama dari suatu objek [1]. Pengenalan pola sendiri merupakan cabang dari kecerdasan buatan (Artificial Inteligence).

\subsection{Sidik Jari}

Sidik jari merupakan sesuatu yang unik dan tidak akan berubah seumur hidup kecuali jika luka parah pada jari [2]. Pola sidik jari selalu ada dalam setiap tangan dan bersifat permanen. Dalam artian, dari bayi hingga dewasa pola itu tidak akan berubah sebagaimana garis tangan. Setiap jari pun memiliki pola sidik jari berbeda. Ada empat pola dasar Dermatoglyphic tentang sidik jari yang perlu diketahui, yakni Whorl atau Swirl, Arch, Loop, dan Triradius. Selain itu hanyalah variasi dari kombinasi keempat pola ini. Pola-pola dapat juga ditemukan pada ruas kedua dan ketiga di setiap jari.

1. Whorl bisa berbentuk sebuah Spiral, Bulls-eye, atau Double Loop. Whorl adalah titik-titik menonjol dan kontras, dan bisa dilihat dengan mudah.

2. Arch Pola ini bisa terlihat sebagai sebuah Flat Arch, atau Tented Arch setiap pola Arch menaik sangat tinggi.

3. Loop dapat menaik ke arah ujung jari, atau menjatuh ke arah pergelangan tangan. Common Loop bergerak ke arah ibu jari, sementara Radial Loop (Loop terbalik) bergerak mengarahkan ujung pemukulnya ke sisi lengan.

1. Loop Umum (Common Loop) Tipe paling umum dari sidik jari adalah Common Loop. Cetakan ini mengungkap kemampuan untuk menggunakan berbagai ide dari berbagai sumber ide, dan mencampurnya dengan gaya yang unik.

2. Loop Memusat (Radial Loop) Sebuah cetakan menukik yang memasuki dan berangkat dari sisi ibu jari tangan disebut Radial Loop (kadang-kadang disebut Reverse Loop, atau Inventor Loop). Jika Common Loop menunjukkan campuran gaya-gaya lain, Radial Loop mengungkapkan kemampuan untuk menciptakan sebuah gaya atau sistem yang sama sekali baru.

3. Double Loop pada umumnya sama seperti dengan Whorl.

4. Triradius (juga disebut "Delta") dapat digunakan untuk menunjuk dengan tepat pusat dari setiap gunung. Gunung-gunung itu kemudian bisa dilihat sebagai terpusat, kecenderungan, atau berpindah.

\subsection{Manutiae}

Minutiae adalah guratan pada sidik jari, dan merupakan titik bertemu atau berpisah suatu garis sidik jari. Fitur minutiae ini terdiri dari ending, core, bifurcation. ending adalah bagian ujung dari sebuah ridge, bifurcation adalah bagian percabangan dari ridge, dan sementara core titik pusat dari sidik jari [3].

\subsection{Citra}

Citra adalah suatu representasi (gambaran), kemiripan, atau imitasi dari suatu objek. Citra sebagai keluaran suatu sistem perekaman data dapat bersifat optik berupa foto, bersifat analog berupa sinyal-sinyal video seperti gambar pada monitor televisi, atau bersifat digital yang dapat langsung disimpan pada suatu media penyimpan.[4]. Citra digital (diskrit) dihasilkan dari citra analog (Kontinu) melalui digitalisasi citra analog terdiri atas penerokan (Sampling) dan kuantisasi 
(Quantization) Penerokan adalah pembagian citra ke dalam elemen-elemen diskrit (Pixel), sedangkan kuantisasi adalah pemberian nilai intensitas warna pada setiap pixel dengan nilai yang berupa bilangan bulat [5].

\subsection{Morfologi Matematika}

Ada dua operasi dasar morphologi yaitu dilasi dan erosi. Kedua operasi dasar tersebut menjadi basis untuk membuat berbagai operasi morphologi yang sangat berguna untuk pengolahan citra digital, seperti opening, closing, hit, and miss transform, thinning, dan thickening [6].

Morfologi matematika pada aplikasi perhitungan jumlah objek ini diterapkan pada citra biner. Morfologi matematika juga dapat diaplikasikan pada citra grayscale maupun warna, namun untuk mendeteksi dan memperjelas bentuk suatu objek akan menghasilkan hasil yang optimal jika diterapkan pada citra biner. Terdapat dua operasi dasar dalam morfologi yaitu dilasi dan erosi, operasi-operasi lainnya juga dapat dibangun dari kombinasi antara keduanya [7].

1. Dilasi (Dilation)

Misalkan A dan B adalah himpunan-himpunan piksel. Dilasi A oleh B dinotasikan dengan A

$\oplus \mathrm{B}$ dan didefinisikan sebagai berikut:

$$
{ }_{A} \bigoplus^{B}=\bigcap_{x \in B} A_{x}
$$

Ini berarti bahwa untuk setiap titik $\mathrm{x} \in \mathrm{B}$, maka dilalkukan translasi atau penggeseran dan kemudian menggabungkan seluruh hasilnya (Union). Atau secara matematis dituliskan sebagai:

$$
A \oplus B=\{(x, y)+(u, v):(x, y) \in A,(u, v) \in B
$$

Dilasi mempunyai hukum komutatif, yaitu:

$$
A \oplus B=B \oplus A
$$

2. Erosi (Erotion)

Jika diketahui himpunan A dan B, maka erosi A oleh B (dinotasikan A $\Theta$ B) didefinisikan sebagai:

$$
A \ominus B=\{\omega: B \omega \subseteq A\}
$$

Sebagaimana pada dilasi, maka pada operasi erosi umumnya A diasumsikan sebagai citra yang akan diproses dan B adalah satu set (himpunan) piksel yang juga disebut structuring element (elemen pembentuk struktur) atau kernel. Erosi didefinisikan sebagai:

$$
A-B=\bigcap_{b \in B} A_{b}
$$

3. Opening

Misalkan terdapat citra A dan structuring element $\mathrm{B}$, maka opening A oleh B dinyatakan dengan notasi $A \square \square B$ dan didefinisikan sebagai berikut:

$$
A \circ B=(A \ominus B) \oplus B
$$

Sehingga operasi opening merupakan sebuah operasi yang terdiri atas operasi erosi diikuti oleh operasi dilasi. 
4. Closing

Closing didefinisikan sebagai operasi dilasi yang dilanjutkan dengan operasi erosi, dinotasikan sebagai $A \square B$, sehingga dapat dinyatakan

$$
A \cdot B=(A \oplus B) \ominus B
$$

\subsection{Jarak Euclidean}

Euclidean Distance atau Jarak Euclidean adalah metrika yang paling sering digunakan untuk menghitung kesamaan dua vektor. Euclidean Distance menghitung akar dari kuadrat dari perbedaan dua vektor [8].

Rumus dari Euclidean Distance:

$$
d_{i j}=\sqrt{\sum_{k=1}^{n}\left(x_{i k}-x_{j k}\right)^{2}}
$$

\section{Metode Penelitian}

\subsection{Bahan Penelitian}

Dalam penelitian ini, bahan penelitian yang akan digunakan adalah hasil studi literatur yang telah dilakukan yang menyangkut tentang metode morfologi matematika dan jarak Euclidean, citra sidik jari, Microsoft Visual Basic.Net 2012, Emgu CV, dan Neurotechnology SDK.

1. Studi Literatur

2. Citra Sidik Jari

3. Microsoft Visual Basic.Net 2012

4. Emgu $C v$

Emgu $C V$ adalah wrapper (pembungkus) .Net untuk OpenCV. Dengan EmguCV, fungsi-fungsi dalam Open $C V$ bisa dipanggil melalui bahasa pemrograman yang compatible (sesuai) dengan .NET seperti $C \#, V B$, dan $V C++$.

5. Neurotechnology

Neurotechnology adalah SDK (Software Development Kit) yang mendukung alat pemindai sidik jari U.are.U. Citra sidik jari yang dihasilkan dari SDK ini adalah citra sidik jari yang memiliki titik-titik minutiae (titik percabangan atau perhentian garis-garis pada sidik jari).

\subsection{Alat Penelitian}

Pada penelitian rancang bangun sistem presensi menggunakan sidik jari, penulis menggunakan alat yaitu laptop dan alat pemindai sidik jari. Pemindai sidik jari adalah sebuah perangkat elektronik yang digunakan untuk menangkap gambar dari pola sidik jari berupa citra digital. Pemindai sidik jari yang digunakan adalah Magic Trax Fingerprint Scanner U.are.U $4000 b$.

\subsection{Tipe Penelitian}

Tipe penelitian yang digunakan adalah tipe penelitian kualitatif berbasis eksperimen. Penelitian eksperimen adalah penelitian yang berusaha mencari pengaruh variabel tertentu terhadap variabel lain dengan kontrol yang ketat [9]. 


\subsection{Tipe Penelitian}

Tipe penelitian yang digunakan adalah tipe penelitian kualitatif berbasis eksperimen. Penelitian eksperimen adalah penelitian yang berusaha mencari pengaruh variabel tertentu terhadap variabel lain dengan kontrol yang ketat [9].

\subsection{Lokasi Penelitian}

Penelitian ini dilakukan di Lembaga Pemasyarakatan Klas IIA Palu Sulawesi Tengah.

\subsection{Tahapan Penelitian}

Adapun tahapan dalam penelitian sebagai berikut:

1. Studi Literatur : Studi literatur adalah mencari referensi teori yang relevan dengan metode yang digunakan yang bersumber dari teks-teks tertulis baik cetak maupun secara online.

2. Perancangan Program : Pada perancangan program, tahapan rancang bangun system presensi menggunakan sidik jari.

3. Pembuatan Program : Pembuatan program antara lain melakukan persiapan software yang akan digunakan, membuat desain dan coding.

4. Pengumpulan Data Sidik Jari : Data primer pada penelitian ini adalah citra sidik jari, data ini diperoleh melakukan pengambilan citra sidik jari pegawai Lembaga Pemasyarakatan Klas IIA Palu. Hasil dari pengumpulan data ini bisa dipakai sebagai bahan untuk membuat menguji program.

5. Menjalankan Program : Setelah pembuatan program dan pengumpulan data sidik jari selesai, selanjutnya menjalankan program untuk mengetahui program yang dibuat dapat melakukan perbaikan dan peningkatan kualitas citra sidik jari serta dapat mendeteksi citra sidik jari.

\section{Hasil dan Pembahasan}

\subsection{Context Diagram}

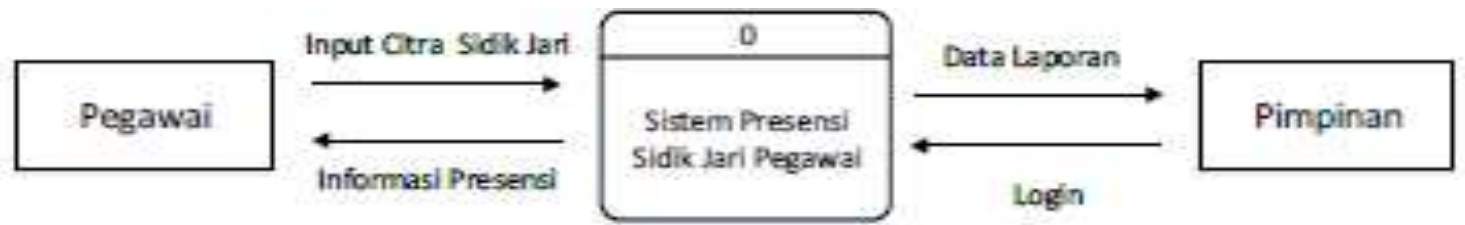

Gambar 1. Context Diagram Sistem Presensi Menggunakan Sidik Jari

Keterangan gambar 1. dapat dilihat pada penjelasan berikut:

a. Pegawai : Pegawai piket melakukan pengambilan citra sidik jari yang kemudian dijadikan citra latih sebagai acuan untuk pencocokan citra uji yang diproses dalam sistem presensi sidik jari pegawai.

b. Sistem Presensi Sidik Jari Pegawai : Sistem presensi sidik jari pegawai memberikan informasi presensi kepada pegawai dan informasi presensi pegawai berupa data dan laporan kehadiran kepada pimpinan. 
c. Pimpinan : Pimpinan menerima data dan laporan kehadiran para pegawai yang telah melakukan presensi sidik jari setelah melakukan proses login.

\subsection{Data Flow Diagram (DFD)}

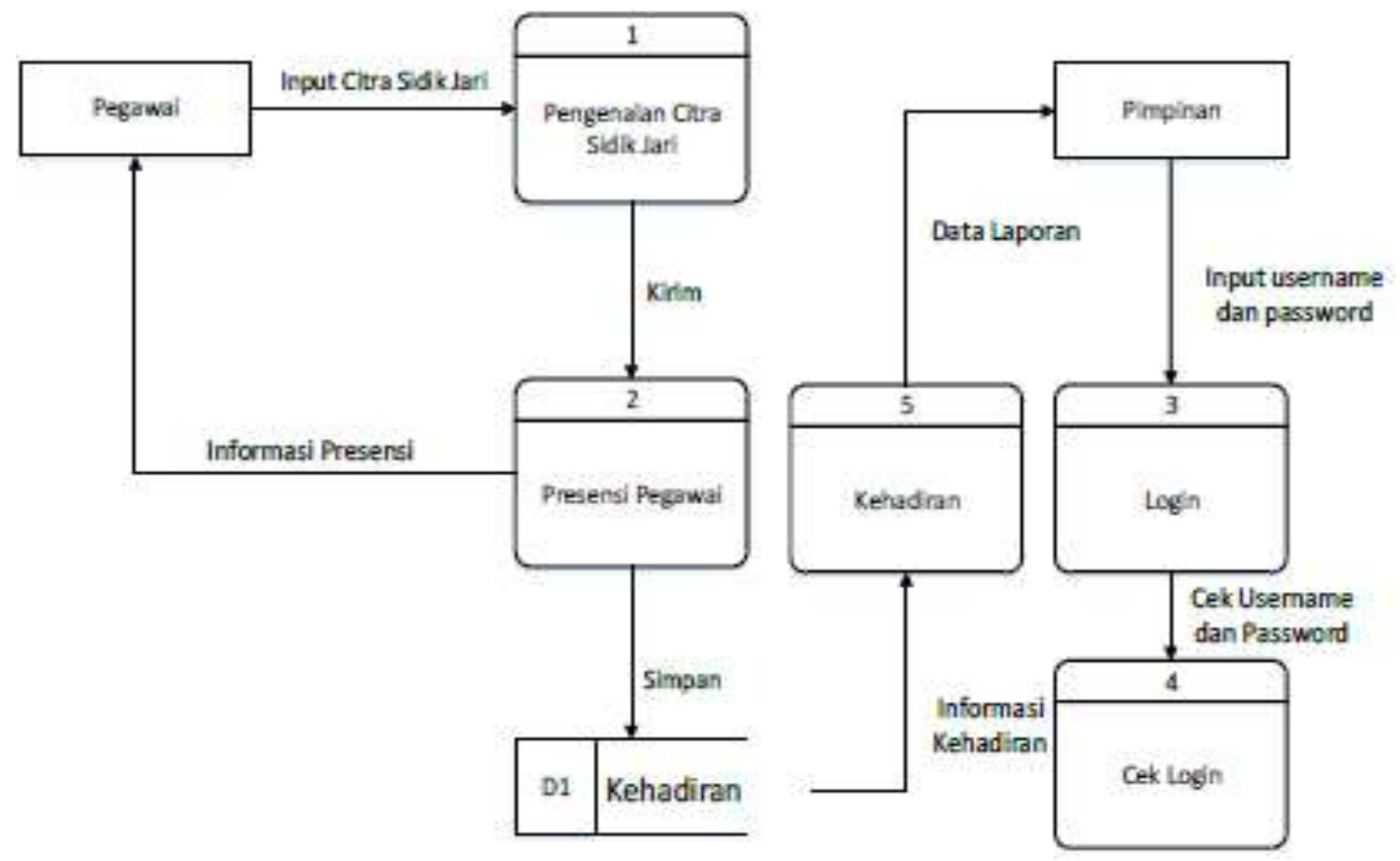

Gambar 2. DFD level 1 Sistem Presensi Menggunakan Sidik Jari

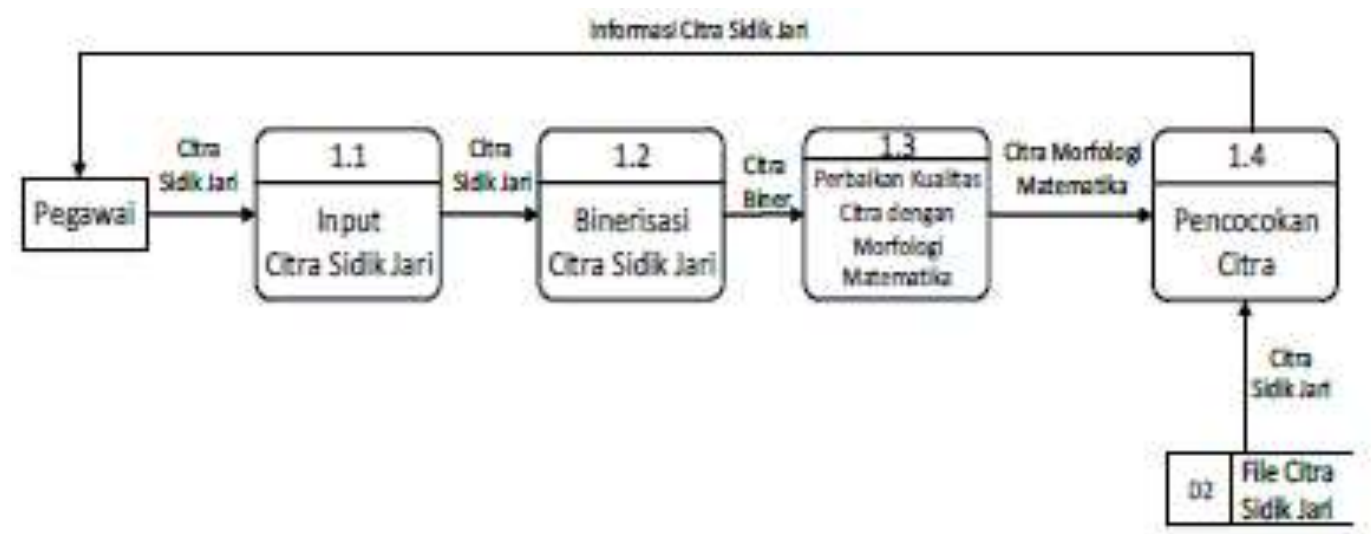

Gambar 3. DFD level 2 Sistem Presensi Menggunakan Sidik Jari

Keterangan gambar 2 dan gambar 3 dapat dilihat pada penjelasan berikut:

a. Pegawai : Pegawai piket melakukan pengambilan citra sidik jari sebagai citra latih atau citra masukan.

b. Presensi Pegawai ; Pada proses ini sistem mengirimkan data pegawai yang telah dikenali pada proses pengenalan sidik jari.

c. Kehadiran Pegawai ; Merupakan penyimpanan data pegawai yang telah melakukan presensi. 
d. Binerisasi Citra Sidik Jari : Binerisasi dilakukan untuk mengubah greylevel citra menjadi citra biner. Hal ini meningkatkan kontras antara ridge dan valley dalam citra sidik jari, dan akibatnya memfasilitasi ekstraksi minutiae. Proses binarisasi melibatkan pemeriksaan tingkat greylevel nilai setiap piksel dalam citra yang disempurnakan, dan jika nilai lebih besar daripada ambang batas, maka nilai piksel disetel ke nilai biner satu, selain itu diatur ke nol. Hasilnya adalah citra biner berisi dua tingkat informasi, latar depan ridge dan latar belakang valley.

e. Perbaikan kualitas citra sidik jari dengan Morfologi Matematika. : Dilakukan perbaikan kualitas citra sidik jari dengan Morfologi Matematika pada citra hasil binerisasi untuk menghasilkan kualitas citra yang cukup bagus.

f. Pencocokan Citra : Proses ini dilakukan dengan menggunakan pengukuran jarak Euclidean pada citra uji dengan semua citra latih dan nilai citra latih yang paling mendekati dengan nilai citra uji akan dianggap sebagai citra yang sama.

\subsection{Entity Relationship Diagram (ERD)}

Data yang digunakan dalam rancang bangun sistem presensi menggunakan sidik jari terdiri dari beberapa tabel. Berikut gambaran relasi tabel yang ada di dalam database.

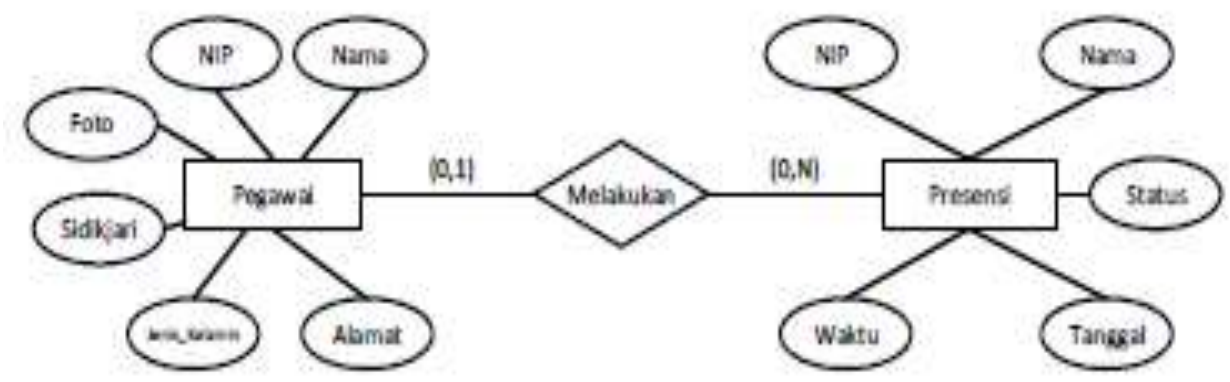

Gambar 4. Entity Relationship Diagram Sistem Presensi Menggunakan Sidik Jari

\subsection{Tampilan Program}

Tampilan Program pada Visual Studio.Net 2012 yaitu:

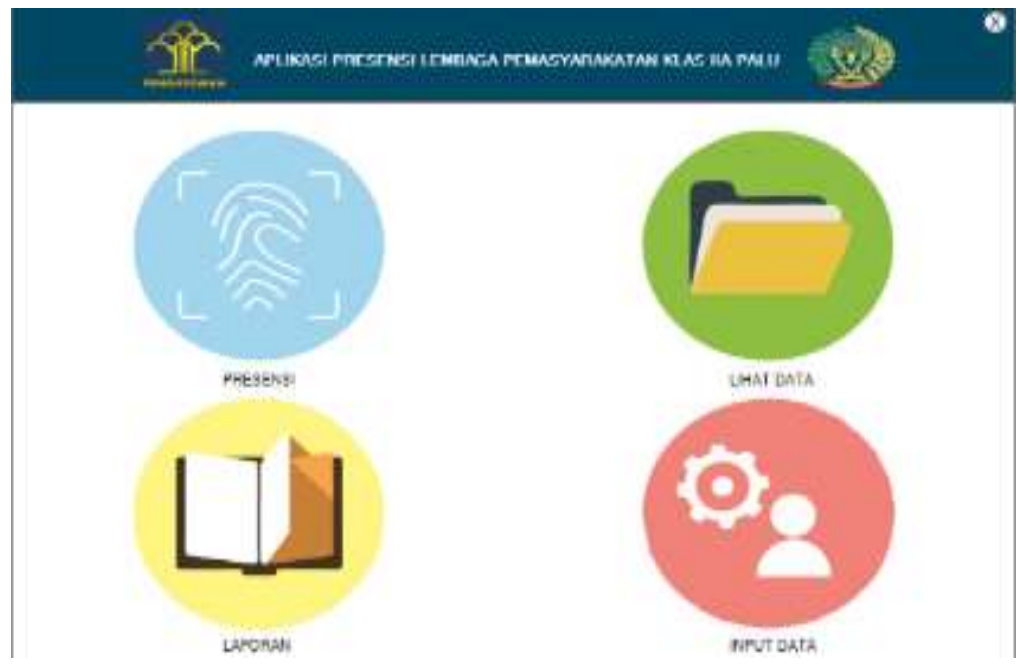

Gambar 5. Tampilan Utama 

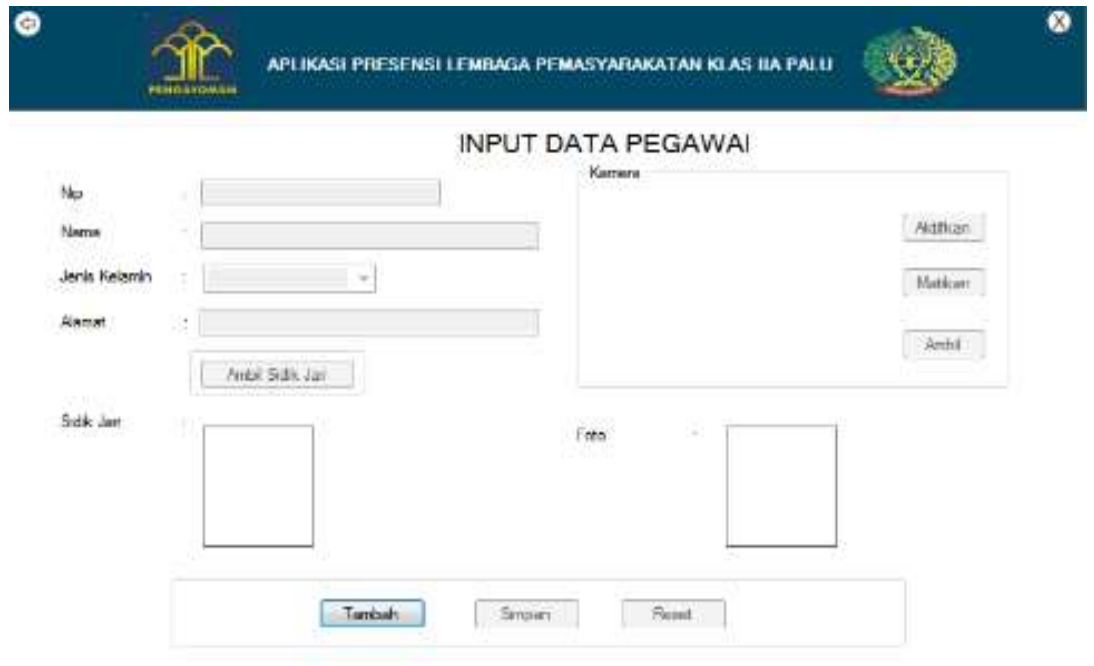

Gambar 6. Form Input Data Pegawai

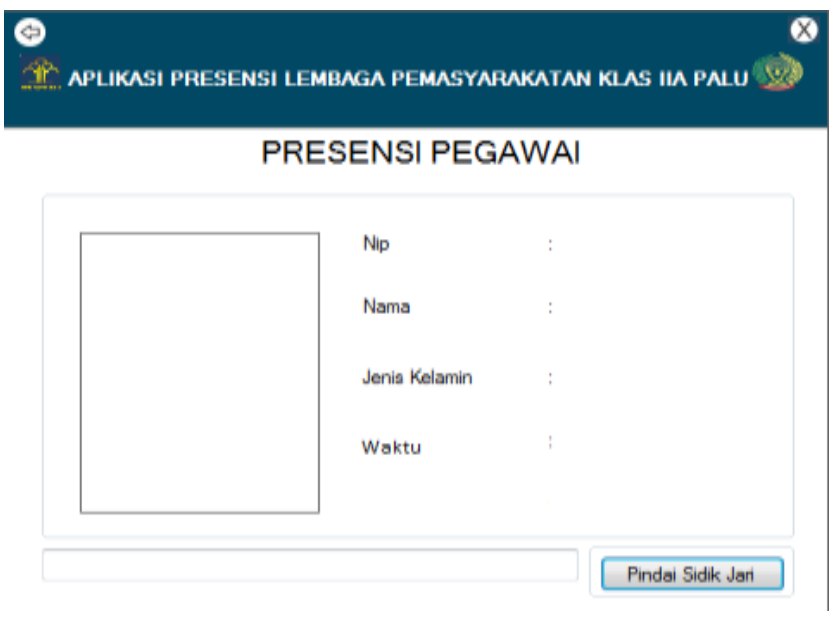

Gambar 7. Form Presensi Pegawai
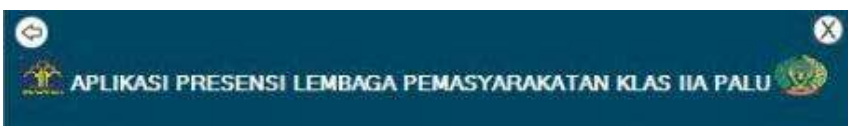

\section{LIHAT DATA PEGAWAI}

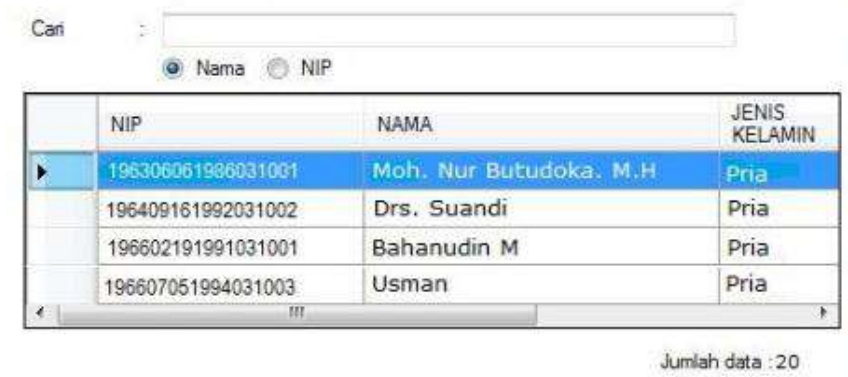

Gambar 8. Form Lihat Data Pegawai 


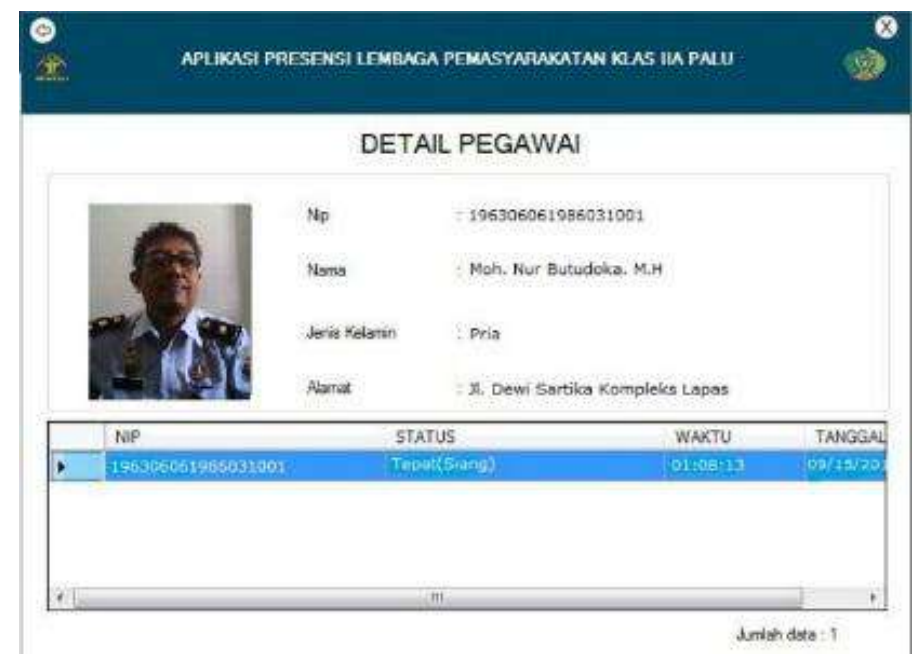

Gambar 9. Form Lihat Detail Pegawai

\begin{tabular}{|c|c|c|}
\hline \multicolumn{3}{|c|}{ LAPORAN PRESENSISELURUH PEGAWAI } \\
\hline & $\operatorname{Tan} 02 \operatorname{sil}$ & 1. October 15.2016 \\
\hline SeIP & Nama & 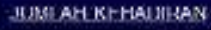 \\
\hline 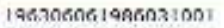 & Moh. Nur Buturtriks, M.H & 100 \\
\hline 196409161992031002 & Ors, suandi & 100 \\
\hline 190602191991031001 & Dethariwedir M & 2,00 \\
\hline 1961607051994031003 & Uxinan & 7,00 \\
\hline
\end{tabular}

Gambar 10. Form Laporan Presensi Seluruh Pegawai

\subsection{Proses Morfologi Matematika}

\subsubsection{Operasi Erosi}

Erosi merupakan proses penghapusan titik-titik objek (1) menjadi bagian dari latar (0) berdasarkan SE yang digunakan. Cara erosi yaitu untuk setiap titik pada citra, lakukan hal berikut:

a. Letakkan titik SE pada titik Citra tersebut

b. Jika ada titik Citra yang cocok dengan titik SE, maka bagian tersebut yang akan diperkecil sehingga nilai titik pusat bernilai 1 dan titik yang lain bernilai 0 .

c. Jika semua nilai titik SE cocok dengan nilai titik Citra $=>$ output $=1$, otherwise output $=0$.

\subsubsection{Operasi Dilatasi}

Dilasi merupakan proses penggabungan titik-titik latar (0) menjadi bagian dari objek (1), berdasarkan SE yang digunakan. Cara dilasi yaitu untuk setiap titik pada Citra, lakukan hal berikut:

a. Letakkan titik SE pada titik Citra tersebut

b. Beri angka 1 untuk semua titik $(\mathrm{x}, \mathrm{y})$ yang terkena oleh SE pada posisi tersebut.

c. Jika ada nilai titik SE cocok dengan nilai titik Citra $=>$ output $=1$, otherwise output $=0$. 


\subsubsection{Perhitungan Jarak Euclidean}

Dengan menggunakan rumus pengukuran jarak Euclidean, jarak-jarak antar titik-titik minutiae akan dihitung kemudian jarak terkecil antar titik-titik minutiae pada citra uji akan dicocokkan dengan jarak terkecil antar titik-titik minutiae pada citra latih. Jarak sama nilainya akan dihitung skornya, dimana jika sama bernilai skor 1 dan jika berbeda nilai skor 0 . Citra uji dengan nilai skor yang paling tinggi akan dianggap sama dengan nilai citra latih yang sudah tersimpan di database.

\section{Kesimpulan}

Berdasarkan pengujian dan analisis rancang bangun sistem presensi menggunakan sidik jari, maka dapat diambil kesimpulan bahwa Penentuan Structuring Elements mempengaruhi citra hasil operasi morfologi matematika dan Tingkat pengenalan dan pencocokan sistem menggunakan proses pengukuran jarak Euclidean dengan perbandingan titik-titik minutiae adalah sebesar 89\% dari 20 data dan 100 kali percobaan. Hal ini berarti bahwa pendeteksian citra sidik jari menggunakan pengukuran jarak Euclidean cukup efektif digunakan untuk melakukan pendeteksian citra sidik jari.

\section{DAFTAR REFERENSI}

[1] Putra, D. 2010. Pengolahan Citra Digital, Penerbit Andi, Yogyakarta.

[2] Maltoni, D., Maio, D., Jain, A., Prabhakar, S. 2003. Handbook of Fingerprint Recognition, Springer, New York.

[3] Gunawan, A., Wikaria, G., Benny, S. 2012. Analisi Sistem Identifikasi Sidik Jari Berbasis Minutiae dan Non-Minutiae, Binus University, Jakarta.

[4] Sutoyo. T., Edy. M., Vincent. S., Oki.D., Wijanarto. 2009. Teori Pengolahan Citra Digital, Penerbit Andi, Yogyakarta.

[5] Awcock, G.W. 1996. Applied Image Processing, McGraw-Hill Book, Singapore.

[6] Putra, D. 2010. Pengolahan Citra Digital, Penerbit Andi, Yogyakarta.

[7] Susilawati, I. 2009. Kuliah 10 - Mathematical Morphology, Universitas Mercu Buana Yogyakarta, Yogyakarta.

[8] Putra, D. 2010. Pengolahan Citra Digital, Penerbit Andi, Yogyakarta.

[9] Sedarmayanti \& Syarifudin Hidayat. 2002. Metodologi Penelitian, Mandar Maju, Bandung. 